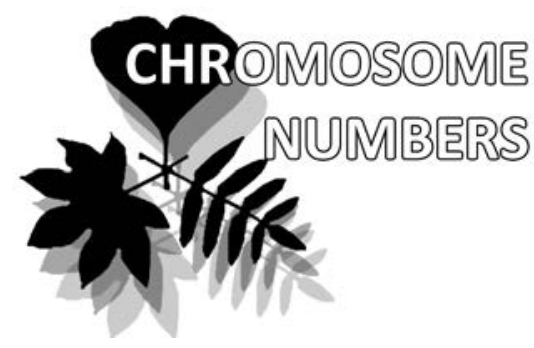

Nina S. Probatova ${ }^{1 *}$

e-mail: probatova@ibss.dvo.ru

Sergey G. Kazanovsky²

e-mail: skazanovsky@mail.ru

Olga A. Chernyagina

e-mail:kamchatika@mail.ru

${ }^{1}$ Federal Scientific Center of the East Asia Terrestrial Biodiversity, FEB RAS, Vladivostok, Russia

${ }^{2}$ Siberian Institute of Plant Physiology \& Biochemistry, SB RAS, Irkutsk, Russia

Kamchatka Branch of the Pacific Geographical Institute FEB RAS,

Petropavlovsk-Kamchatskii, Russia

*corresponding author

Manuscript received: 25.10.2018 Review completed: 30.10 .2018 Accepted for publication: 31.10.2018 Published online: 03.11.2018

\title{
Chromosome numbers in some vascular plant species from Russia: Komi Republic, Volga Region, Siberia and the Far East
}

\author{
Nina S. Probatova ${ }^{1 *}$, Sergey G. Kazanovsky ${ }^{2} \&$ Olga A. Chernyagina ${ }^{3}$
}

\begin{abstract}
A B S T R A C T
The chromosome numbers (2n) for 26 vascular plant species of 21 genera from 10 families: Asteraceae: Aster, Pilosella; Caryophyllaceae: Cerastium, Gypsophila, Moehringia, Stellaria; Fabaceae: Glycyrrbiza; Geraniaceae: Erodium; Lamiaceae: Amethystea, Galeopsis, Thymus; Paeoniaceae: Paeonia; Poaceae: Brachypodium, Deschampsia, Elymus, Eremopyrum, Melica, Poa; Ranunculaceae: Ranunculus; Rosaceae: Fragaria; Valerianaceae: Patrinia, from European Russia (Komi Republic, Astrakhanskava Oblast'), Siberia (Altai Republic, Altaiskii Krai, Irkutskaya Oblast') and the Russian Far East (Primorskii Krai, Kamchatka Peninsula) are presented. The CNs are first studied in Pilosella vaillantii, Thymus mongolicus and T. roseus. The first CN count from Russia - for Cerastium davuricum, from Siberia - for Moebringia lateriflora. Poa urssulensis is studied for the first time from Altai, Ranunculus sceleratus and Elymus sibiricus - from Kamchatka, Erodium cicutarium - from Irkutskaya Oblast', E. stephanianum - from Primorskii Krai. Poa sajanensis is reported firstly for Europe (Komi Republic).
\end{abstract}

Ke yw ords : chromosome numbers, vascular plants, Komi Republic, Volga Region, Siberia, Far East, Russia

\section{P E 3 Ю M E}

Пробатова Н.С., Казановский С.Г., Чернягина О.А. Числа хромосом некоторых видов сосудистых растений из России: Республика Коми, Поволжье, Сибирь и Аальний Восток. Приводятся числа хромосом (2n) Аля 26 вилов сосудистых растений из 21 рода и 10 семейств: Asteraceae: $A s-$ ter, Pilosella; Caryophyllaceae: Cerastium, Gypsophila, Moebringia, Stellaria; Fabaceae: Glycyrrbiza; Geraniaceae: Erodium; Lamiaceae: Amethystea, Galeopsis, Thymus; Paeoniaceae: Paeonia; Poaceae: Brachypodium, Deschampsia, Elymus, Eremopyrum, Melica, Poa; Ranunculaceae: Ranunculus; Rosaceae: Fragaria; Valerianaceae: Patrinia, - из Европейской России (Респуб̆лика Коми, Астраханская область), Сибири (Республика Алтай, Алтайский край, Иркутская область) и Аальнего Востока (Приморский Край, п-ов Камчатка). Впервые исследованы в кариологическом отношении Pilosella vaillantii, Thymus mongolicus и T. roseus. Впервые Аля России исследовано число хромосом у Cerastium davuricum, впервые Аля Сибири - у Moebringia lateriflora. Poa urssulensis впервые исследован с А^тая, Ranunculus sceleratus и Elymus sibiricus - с Камчатки, Erodium cicutarium - из Иркутской области, E. stephanianum - из Приморского края. Poa sajanensis впервые указывается Аля Европы (Республика Коми).

К $\boldsymbol{\Lambda}$ ю че в ы е с $\mathbf{~ о ~ в ~ а ~ : ~ ч и с л а ~ х р о м о с о м , ~ с о с у д и с т ы е ~ р а с т е н и я , ~ Р е с п у б и и к а ~ К о м и , ~}$ Волжский регион, Сибирь, Аальний Восток, Россия
Here we present further results of chromosome number (CN) study of 26 vascular plant species from Russia, mainly from Siberia and the Russian Far East (RFE), as well as from European Russia - Komi Republic and Astrakhanskaya Oblast' - Volga Region (Fig. 1). This contribution continue the series of previous publications by Probatova et al.

Chromosome countings were made with participation of E.G. Rudyka, on squashed preparations of root tips fixed with Carnoy's solution. The root tips were taken mostly from seedlings obtained through herbarium specimens, which were collected in the field. Preparations were stained with iron hematoxylin. Voucher specimens are preserved in the Herbarium VLA, Vladivostok (some - in IRK, Irkutsk). First $\mathrm{CN}$ data are indicated by asterisk $(*)$. The number of the dot on the map follows the number of voucher specimen. Brief information on the affinity and distribution of the species studied is given.

\begin{abstract}
ASTERACEAE
Aster ageratoides Turcz., $2 \mathrm{n}=18$

Russia, Far East, Primorskii Krai, Dal'negorskii Raion, in vicinity of Dal'negorsk town, the Rudnaya River basin, ca. 400 $\mathrm{m}$ alt., Barachnaya Pad' locality, oak forest (Quercus mongolica), 28 Sep 2017, coll. O.A. Chernyagina 13221: 1 (VLA). Distribution: south of Primorskii Krai and of the Amur River basin; China, Korean Peninsula, ?Japan. Oak forests, mixed forests, among shrubs. Described from China. Diploid $(2 \mathrm{n}=$ $2 \mathrm{x}, \mathrm{x}=9)$. All $\mathrm{CN}$ counts for this species hitherto made from Primorye show $2 \mathrm{n}=18$ (see Probatova 2014 and references therein). We suppose that $A$. ageratoides complex is represented in China, Taiwan, Korea and Japan not only by diploids, but by series of high polyploid $\mathrm{CN}$ s wich were reported under this name (see in Nishikawa 2008).
\end{abstract}

*Pilosella vaillantii (Tausch) Soják (Hieracium vaillantii Tausch), $2 \mathrm{n}=18$

Russia, West Siberia, Altaiskii Krai, Charyshskii Raion, left riverside of the Charysh River, near Krasnyi Partizan 


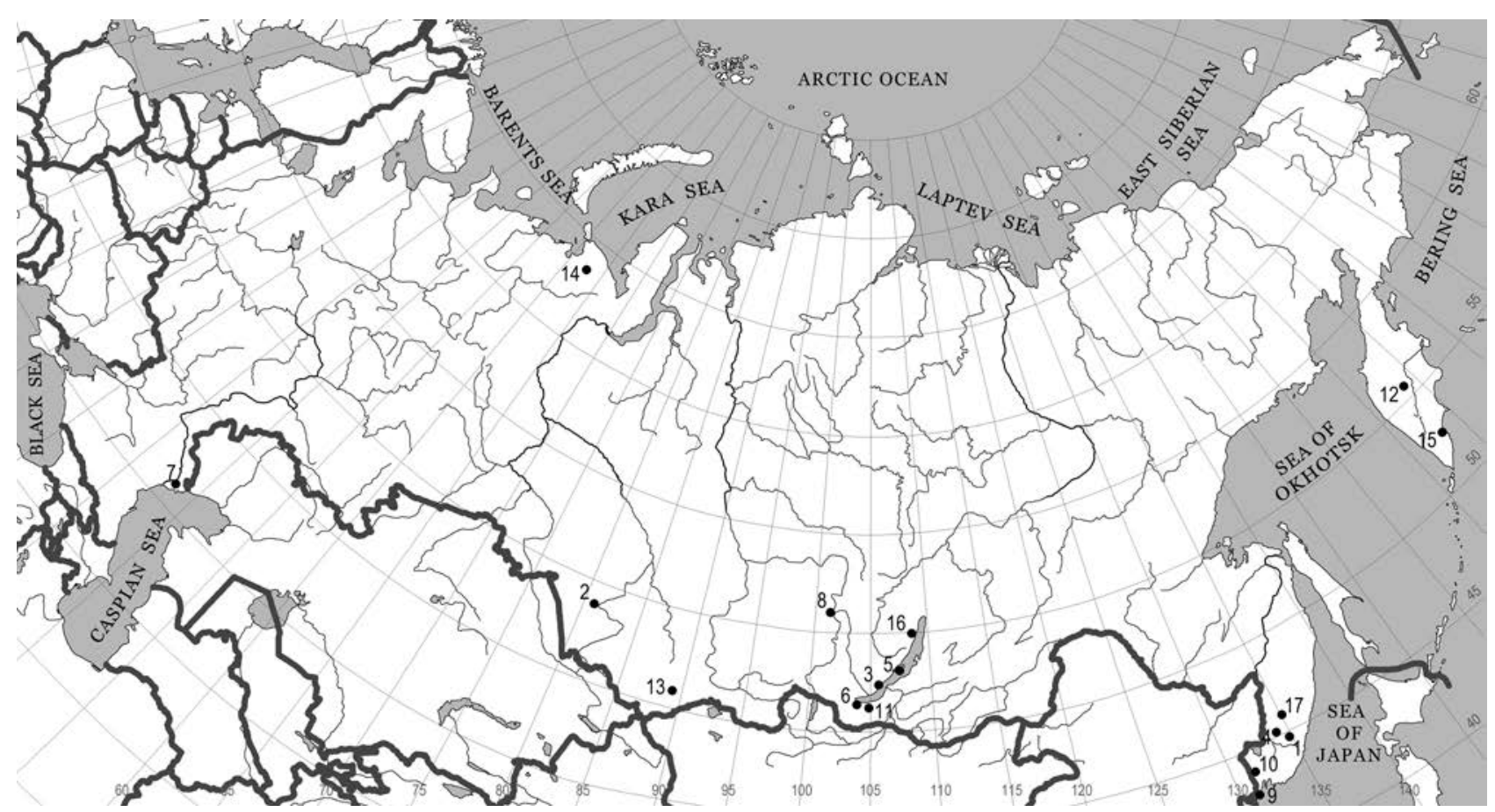

Figure 1 Study area. Dots with numbers from 1 to 17 are the sampling plot locations (according to numbering in the text)

village, the Altaiskii University practice base, $511 \mathrm{~m}$ alt., the steppe slope with rocky outcrops, 5 Jul 2016, coll. S.G. Kazanovsky 13257: 2 (IRK, VLA). Distribution: Europe, West Siberia. In Pinus and Betula forests, meadows, as a weed in the fields. Described from Bohemia. Not often in Altai. Diploid $(2 \mathrm{n}=2 \mathrm{x} ; \mathrm{x}=9)$. The first $\mathrm{CN}$ count for the species.

\section{CARYOPHYLLACEAE}

Cerastium davuricum Fisch. ex Spreng., $2 n=38$

Russia, East Siberia, Irkutskaya Oblast', Irkutskii Raion, near Bol'shoe Goloustnoe settlement, the Uglovaya River - left tributary of Goloustnava River, $492 \mathrm{~m}$ alt., riverside birch grass-forb forest, 21 Jul 2014, coll. S.G. Kazanovsky 13183: 3. (IRK, VLA). Distribution: Europe, Siberia, Central Asia. Mountain meadows, forest edges, riverside pebbles, among shrubs. Described from the Baikal Siberia. Diploid $(2 \mathrm{n}=2 \mathrm{x} ; \mathrm{x}=19)$. The $\mathrm{CN}$ of this species was determined several times (see Fedorov 1969 and references therein). The first CN count for Russia.

\section{Gypsophila violacea (Ledeb.) Fenz1, 2n = 34}

Russia, Far East, Primorskii Krai, Chugujevskii Raion, the Ussuri River basin, national park "Zov tigra", the slope of Snezhnava Mt., near the source of Ussuri River, dry stony slide-rocks, 30 Sep 2017, coll. O.A. Chernyagina 13218: 4 (VLA). Distribution: East Siberia (Yakutia, rare), Far East. On rocks, stony and rubbly slopes, up to $1800 \mathrm{~m}$ alt. Described from Khabarovskii Krai (Okhotsk). The third CN count for the species; it was studied first from near Magadan $(2 \mathrm{n}=34-$ Zhukova 1982), but $2 \mathrm{n}=36$ (Rudyka 1990) was erroneous. Diploid $(2 \mathrm{n}=2 \mathrm{x} ; \mathrm{x}=17)$.

\section{Moehringia lateriflora (L.) Fenzl, 2n $=24$}

Russia, East Siberia, Irkutskaya Oblast', Ol'khonskii Raion, Ol'khon Island, in vicinity of the Shara-Nur Lake, Pinus forest with forbs, 14 Aug 2014, coll. S.G. Kazanovsky 13173: 5 (IRK, VLA). Distribution: Holarctic. In coniferous, mixed and broadleaved forests, forest clearings, among shrubs, along riversides, in wet meadows, rarely in seacoasts, on sand dunes. Described from Siberia. Polymorphous species. Variable ploidy. This is the first $\mathrm{CN}$ count for Siberia and moreover, the first finding of diploid cytotype $(2 \mathrm{n}=2 \mathrm{x} ; \mathrm{x}=12)$, which is common in the RFE (see
Probatova 2014 and references therein), where $2 \mathrm{n}=48$ also occurs (reported from West Chukotka by Zhukova 1967).

\section{Stellaria daburica Willd. ex Schlecht., 2n $=78$}

Russia, East Siberia, Irkutskaya Oblast', Irkutskii Raion, near Bol'shoe Goloustnoe settlement, the delta of Goloustnaya River, 489 m alt., grass-forb meadow, 22 Jul 2014, coll. S. G. Kazanovsky 13181: 3 (IRK, VLA). Distribution: East Siberia, Monorolia. On riverside pebbles, lakesides, meadows. Described from Dauria. Diploid $(2 n=2 x ; x=19)$. This CN $2 n=78$ have been established already in the species from West Chukotka, An'ujskoe upland (Zhukova \& Petrovsky 1980, Antonova \& Petrovsky 1986).

\section{Stellaria media (L.) Vill, $2 \mathrm{n}=22$}

Russia, East Siberia, Irkutskava Oblast', Sljudjanskii Raion, left riverside of the Sljudjanka River, $636 \mathrm{~m}$ alt., moist meadow at the output of spring water from under the rock, 21 Aug 2015, coll. S.G. Kazanovsky 13161: 6 (IRK VLA). Distribution: Europe, but everywhere as alien and weedy plant. In the fields, vegetable gardens, forest glades, flowerbeds, roadsides, moist places. Described from Europe. Very polymorphous species, with multiple cytotypes, partly aneuploids $(2 \mathrm{n}=20,22,40,42,44)$. The first finding of diploid cytotype $(2 \mathrm{x} ; \mathrm{x}=11)$ from Siberia. Previously there was only one CN report from Siberia, but it was tetraploid CN $2 n=44$ (see Chepinoga 2014 and references therein).

\section{FABACEAE}

\section{Glycyrrbiza foetidissima Tausch, $2 \mathrm{n}=16$}

Russia, Volga Region, Astrakhanskaya Oblast', Astrakhan' city, outskirts of Babaevskii Raion, burned forests and moist floodplains, 20 May 2017, coll. O.A. Chernyagina 13228: 7 (VLA). Distribution: SE Europe, Caucasus, Mediterranea, Middle Asia. Meadows, steppe slopes, solonetz lands, among shrubs, along the roads. Described from Europe. Diploid (2n $=2 \mathrm{x} ; \mathrm{x}=8)$. Second $\mathrm{CN}$ report for the species.

\section{GERANIACEAE}

Erodium cicutarium (L.) L'Hér., $2 \mathrm{n}=40$

Russia, East Siberia, Irkutskaya Oblast', Zalarinskii Raion, Bazhir settlement, biological station of the Siberian Institute of Plant Physiology \& Biochemistry SB RAS, 507 m 
alt., the first year fallow, 19 Aug 2016, coll. S.G. Kazanovsky 13154: 8 (IRK, VLA). Almost cosmopolitain, but adventive in many regions. Weedy places, fallows, roadsides. Described from Europe. First CN count from Irkutskaya Oblast'. Tetraploid $(2 \mathrm{n}=4 \mathrm{x} ; \mathrm{x}=10)$. Before it was only one report from Siberia $(2 \mathrm{n}=18)$, perhaps erroneous, or belonging to the next species (see Chepinoga 2014 and references therein).

\section{**Erodium stephanianum Willd., $2 \mathrm{n}=20$}

Russia, Far East, Primorskii Krai, Khassanskii Raion, the Reid Pallada Bay, near Mramornyi Cape, sandy-pebbly maritime terrace, on the territory of recreation center, 17 Jun 2014, coll. V.Yu. Barkalov 13247: 9 (VLA). SiberianCentral Asian species, alien elsewhere and in the Russian Far East. Waste places, at roadsides. Described from East Siberia (Dauria). First count of diploid cytotype $(2 \mathrm{x} ; \mathrm{x}=10)$ for this species. However from Mongolia $2 \mathrm{n}=16$ was reported (Mešrcek \& Sojăk 1995). Polybasic species? Variable ploidy? First CN count from Primorskii Krai.

\section{LAMIACEAE}

\section{Amethystea caerulea L., $2 \mathrm{n}=26$}

Russia, East Siberia, Irkutskaya Oblast', Zalarinskii Raion, Bazhir settlement, biological station of the Siberian Institute of Plant Physiology \& Biochemistry SB RAS, $507 \mathrm{~m}$ alt., the first year fallow, 19 Aug 2016, coll. S.G. Kazanovsky 13172: 8 (IRK, VLA). Distribution: Siberia, Central and East Asia. Steppe slopes, riversides, sandy-pebble banks, stony slide-rocks, waste places, roadsides, as a weed on plantations. Described from Siberia. Several CN counts from Primorskii Krai. The CN is constant. There was only one $\mathrm{CN}$ report from Siberia (see Chepinoga 2014 and references therein): $2 \mathrm{n}=26$. Diploid $(2 \mathrm{n}=2 \mathrm{x} ; \mathrm{x}=13)$.

\section{Galeopsis ladanum L., 2n = 16}

Russia, East Siberia, Irkutskaya Oblast', Zalarinskii Raion, Bazhir settlement, biological station of the Siberian Institute of Plant Physiology \& Biochemistry SB RAS, $507 \mathrm{~m}$ alt., the first year fallow, 19 Aug 2016, coll. S.G. Kazanovsky 13219: 8 (IRK, VLA). Distribution: Europe, Mediterranea,West Siberia, alien in the East Siberia and the Russian Far East. Waste grounds, fallows, roadsides. Described from Europe. Many $\mathrm{CN}$ counts, and the $\mathrm{CN}$ is constant. Diploid $(2 \mathrm{n}=2 \mathrm{x} ; \mathrm{x}=8)$.

\section{*Thymus mongolicus (Ronn. ex Diels) Ronn., 2n = 24}

Russia, Far East, Primorskii Krai, Oktyabr'skii Raion, near Novo-Georgievka settlement, the valley of Razdol'naya (Suifun) River, on pebbles, 8 Jul 2009, V.A. Nechaev 11399: 10 (VLA). Distribution: South Siberia, Central Asia, south of the RFE. Stony slopes, rocks, sometimes on limestone. Described from East Kazakhstan. First CN count for the species. Diploid? $(2 \mathrm{n}=2 \mathrm{x} ; \mathrm{x}=12)$.

\section{*Thymus roseus Schipczinsky, $2 \mathrm{n}=24$}

Russia, West Siberia, Altaiskii Krai, Charyshskii Raion, left riverside of the Charysh River, near Krasnyi Partizan village, the Altaiskii University practice base, $511 \mathrm{~m}$ alt., the steppe slope with rocky outcrops, 5 Jul 2016, coll. S.G. Kazanovsky 13270: 2 (IRK, VLA). Distribution: West Siberia; Central Asia. Stony slopes, rocks and slide-rocks. Described from Kazakhstan. The first CN count for the species. Diploid ? $(2 \mathrm{n}=2 \mathrm{x} ; \mathrm{x}=12)$.

\section{PAEONIACEAE}

\section{Paeonia obovata Maxim., $2 \mathrm{n}=20$}

Russia, Far East, Primorskii Krai, Chuguevskii Raion, the Ussuri River basin, the national park "Zov Tigra", the macroslope of Snezhnaya Mt., $1031 \mathrm{~m}$, Picea forest, 30 Sep 2017, coll. O.A. Chernyagina 13201: 4 (VLA). Distribution: Amur, Sakhalin, South Kurils; China, Korea, Japan. Coniferous, mixed and deciduous forests, in river valleys and on the slopes, among shrubs. Described from Lower Amur River basin. Up to now, in Primorskii Krai the diploid CN 2n $=10$ was revealed in $P$. obovata two times, and once $-2 \mathrm{n}=$
20 for P. japonica, its synonym (see Probatova 2014 and references therein). This species in whole have been studying many times, but only from China there were reported two $\mathrm{CNs}-2 \mathrm{n}=10$ and 20 (Hong, Zhang et al. 1988, Hong, Pan et al. 2001, Sang 2004); the same, obviously, is observed in Primorye. Further studies are needed. Variable ploidy $(2 \mathrm{n}=$ $2 \mathrm{x}, 4 \mathrm{x} ; \mathrm{x}=5)$.

\section{POACEAE}

\section{Brachypodium pinnatum (L.) P. Beauv., 2n $=14$}

Russia, East Siberia, Irkutskaya Oblast', Sljudjanskii Raion, lower course of the Sljudjanka River, left riverside, $655 \mathrm{~m}$ alt., SSE slope with outcrops of crystalline limestone, light Betula forest with grasses and forbs, 8 Aug 2015, coll. S.G. Kazanovsky 13162: 6 (IRK, VLA). Distribution: Europe, Central Asia, Siberia (to the West Transbaikalia). Forest glades and clearings, light forests, among shrubs. Described from Europe. This species has eastern border of its area of distribution in south part of the Baikal Siberia. It is peculiar by its CNs, they are not constant within the species: $2 \mathrm{n}=14$ was known from Leningradskaya Oblast' (Sokolovskaya 1972) and from Kazakhstan Republic (Probatova, Kazanovsky, Rudyka et al. 2012), $2 \mathrm{n}=18$ - from Novossibirskaya Oblast', the same CN - also from Kazakhstan (Probatova, Kazanovsky, Rudyka et al. 2012), $2 \mathrm{n}=20$ - from Azerbaidzhan Republic (Sokolovskaya \& Probatova 1978). Moreover, the $2 \mathrm{n}=28$ previously was registered from Permskii Krai (Guzik 1984) and from elsewhere, reported by many authors (see Chromosome numbers... 1969 and references therein). Polybasic species?

\section{Deschampsia turczaninowii (Litv.) Roshev., $2 \mathrm{n}=26$}

Russia, East Siberia, Irkutskaya Oblast', Sljudjanskii Raion, the Krugobaikal'skaya railway, 141-th km, near the mouth of Bol'shaya Krutaya Guba River, on moist sands of Baikal Lake, 1 Sep 2014, coll. M.M. Ivanova 13157: 11 (IRK, VLA). Distribution: endemic of Baikal. On sands and gravels of the Baikal lakesides. Described from Baikal (Svyatoi Nos Peninsula). Sometimes the pseudoviviparous spikelets occur in the panicles. $2 \mathrm{n}=26$ (Probatova, Gnutikov, Rudyka et al. 2008). Diploid $(2 \mathrm{n}=2 \mathrm{x} ; \mathrm{x}=13)$.

\section{Elymus sibiricus $\mathrm{L}$., $2 \mathrm{n}=28$}

Russia, Far East, Kamchatskii Krai, Kamchatka Peninsula, Bystrinskii Raion, Esso settlement, on roadside, 25 Aug 2017, coll. O.A. Chernyagina 13192: 12 (VLA). Distribution: E Europe, Siberia, Central and East Asia - NW America; elsewhere as alien. On sands and gravels of riversides, on the slopes, among shrubs, in forest glades, at the roads, in settlements. Described from Siberia. Well studied species in Siberia and the RFE, but still there was no CN count from Kamchatka. Tetraploid $(2 \mathrm{n}=4 \mathrm{x} ; \mathrm{x}=7)$; there are no diploid species in the genus Elymus $\mathrm{L}$.

\section{Eremopyrum orientale (L.) Jaub et Spach, $2 \mathrm{n}=28$}

Russia, Volga Region, Astrakhanskaya Oblast', Astrakhan' city, Babaevskii Raion, dry roadside in the floodplain, abundant, 20 May 2017, coll. O.A. Chernyagina 13229: 7 (VLA). Distribution: SE and S Europe, Caucasus, Central Asia; elsewhere as alien. In steppes and semi-deserts, on sands, loamy and stony slopes, as alien at the roads. Described from the Aegean Sea islands. Tetraploid $(2 \mathrm{n}=4 \mathrm{x} ; \mathrm{x}=7)$. Well studied species. This $\mathrm{CN}$ was also revealed from Crimea (see Agapova et al. 1993 and references therein). Tetraploid $(2 \mathrm{n}=4 \mathrm{x} ; \mathrm{x}=7)$.

\section{Eremopyrum triticeum (Gaertn.) Nevski, 2n = 14}

Russia, Volga Region, Astrakhanskaya Oblast', Astrakhan' city, Babaevskii Raion, dry roadside in the floodplain, abundant, 20 May 2017, coll. O.A. Chernyagina 13227: 7 (VLA). Distribution: SE Europe, Caucasus, Central Asia; elsewhere as alien. In steppes and semi-deserts, on sands and pebbles, saline places, stony slopes, at the roads and in settlements. Described from the Urals. This CN was also revealed from Crimea (see Agapova et al. 1993 and references therein) and Daghestan (Probatova, Seledets, Rudyka, 2016). The CN is constant. Diploid $(2 n=2 x ; x=7)$. 


\section{Melica transsilvanica Schur, $2 \mathrm{n}=18$}

Russia, West Siberia, Republic of Altai, Chemal'skii Raion, right riverside of the Katun' River, at the mouth of Bel'tirtujuk River, 614 m alt., rocky steppe slope, 3 Jul 2016, coll. S.G. Kazanovsky 13268: 13 (IRK, VLA). Distribution: SE Europe, Caucasus, W Siberia - Central Asia. In steppes, forest edges and glades, on stony slopes, on rocks, among shrubs. Described from Romania. Many CN counts from Russia and neighbouring countries. Diploid $(2 \mathrm{n}=2 \mathrm{x}$; $\mathrm{x}=$ 9). This $\mathrm{CN}$ is constant in all the genus Melica $\mathrm{L}$.

\section{**Poa sajanensis $\mathrm{Roshev.,} 2 \mathrm{n}=\mathrm{c.64}$}

Russia, European part, Komi Republic [Komi ASSR], Intinskii Raion, sovkhoz "Gornyak", Yun'-Yaga farm, forb meadow on the right riverside of the Yun'-Yaga River, 10 VII 1967 coll. A.P. Sokolovskaya \& N.N. Tzvelev 34: 14 (VLA). Distribution: North of European Russia, East Siberia, North of the Russian Far East; North America (Alaska). Meadows in tundra, riverside sands and pebbles. Described from East Sayan Mts. Poorly studied species. Formerly it was misidentified as Poa pratensis L. or P. sublanata Reverd. Previously the CNs $2 \mathrm{n}=56$ and c. 70 from Kamchatka, North Koryakia and Bering Isl. were reported (Sokolovskaya \& Probatova 1968; Probatova \& Seledets 2008 - as $P$. sublanata). Here is the new $\mathrm{CN}$ for $P$. sajanensis and the first record of this species from Europe. Variable ploidy.

\section{Poa urssulensis Trin., $2 \mathrm{n}=28$}

Russia, West Siberia, Altaiskii Krai, Charyshskii Raion, left riverside of the Charysh River, near Krasnyi Partizan village, the Altaiskii University practice base, $511 \mathrm{~m}$ alt., the steppe slope with rocky outcrops, 5 Jul 2016, coll. S.G. Kazanovsky 13258: 2 (IRK, VLA). Distribution: mostly South Siberia - Russian Far East, and in Middle, Central and S Asia. In lighted and dry forests, forest glades, among shrubs, on stony slopes, rocks and pebbles. Described from Altai (the Urssul River). Species with variable ploidy: $2 \mathrm{n}=$ 28, 42 (4x, 6x); these CNs were reported earlier from Amurskaya Oblast' (see Agapova et al. 1993 and references therein), $2 \mathrm{n}=28$ - from Novossibirskaya Oblast' (Krasnikov 1991). Too little studied species. First CN count from Altai. The species probably has hybrid origin, from $P$. transbaicalica Roshev. and P. palustris or P. nemoralis (Tzvelev 2010).

\section{RANUNCULACEAE}

\section{Ranunculus sceleratus $\mathrm{L} ., 2 \mathrm{n}=56$}

Russia, Far East, Kamchatskii Krai, Kamchatka Peninsula, suburbs of Petropavlovsk-Kamchatskii city, Malava Lagernaya Bay, coastal sands, at the freshwater lake, humid zone with anthropogenic impact, 19 Sep 2016, coll. O.A. Chernyagina \& E.A. Devyatova 13217: 15 (VLA). Distribution: Holarctic. Riverbanks, seacoasts, sometimes as alien. Anthropophyte, halophyte. Many CN counts throughout the world: mostly $2 \mathrm{n}=32$, less $2 \mathrm{n}=64$; however the Far East populations obviously have another basic $\mathrm{CN}$ number than elsewhere (see Probatova 2014 and references therein). The $\mathrm{CN} 2 \mathrm{n}=56$ is known (but rare) also in Zabaikal'skii Krai (see Chepinoga 2014 and references therein). Variable ploidy $(2 \mathrm{n}=2 \mathrm{x}, 4 \mathrm{x}, 8 \mathrm{x} ; \mathrm{x}=? 7,8)$. Further studies are needed. First $\mathrm{CN}$ count from Kamchatka.

\section{ROSACEAE}

\section{Fragaria vesca $L$., $2 \mathrm{n}=14$}

Russia, East Siberia, Irkutskaya Oblast', KazachinskoLenskii Raion, near the railway station Kunerma, $502 \mathrm{~m}$ alt. Populus tremula and Betula forest with Vaccinium myrtillus and small herbs, 11 Aug 2014, coll. S.G. Kazanovsky 13260: 16 (IRK, VLA). Distribution: Euro-Siberian - Mediterranean; alien in North America. Described from North Europe. Multiple $\mathrm{CN}$ counts give the same diploid number $2 \mathrm{n}=14$ $(2 \mathrm{n}=2 \mathrm{x} ; \mathrm{x}=7)$.

\section{VALERIANACEAE}

\section{Patrinia rupestris (Pall.) Dufr., 2n $=22$}

Russia, Far East, Primorskii Krai, Kavalerovskii Raion, Kavalerovo settlement, the rocks Dersu Uzala, Zerkal'naya
River basin, $298 \mathrm{~m}$ alt., the floodplaine, dry slide-rocks, 29 Sep 2017, coll. O.A. Chernyagina 13262: 17 (VLA). Distribution: Siberia, Far East. Stony, rubbly and dry sandy slopes. Described from Dauria. Diploid $(2 \mathrm{n}=2 \mathrm{x}$; $\mathrm{x}=11)$. The $\mathrm{CN}$ is constant.

\section{CONCLUSION}

Most of the species studied are diploids, with different basic numbers: $\mathrm{x}=7,8,9,10,11,12,13,17,19$. Only 3 species have tetraploid CNs (Elymus sibiricus and 2 species of Eremopyrum). Almost $1 / 3$ of the species studied have variable ploidy, and in 2 species (Brachypodium pinnatum and Ranunculus sceleratus) the basic CNs are not constant. The $\mathrm{CNs}$ are first studied in Pilosella vaillantii, Thymus mongolicus and T. roseus. In Ranunculus sceleratus, first studied from Kamchatka, the $\mathrm{CN} 2 \mathrm{n}=56$ was confirmed, though this $\mathrm{CN}$ is not characteristic for this species out of the Russian Far East. In Siberia the CN in Moehringia lateriflora was determined for the first time, and it appeared as the minimal for this species. The diploid cytotype we discovered in Siberia for Stellaria media as well. Poa urssulensis was analysed first from Altai, Ranunculus sceleratus and Elymus sibiricus - from Kamchatka, Erodium cicutarium - from Irkutskaya Oblast', E. stephanianum - from Primorskii Krai. Brachypodium pinnatum was studied at the east limit of its area of distribution (in Baikal Siberia). In Paeonia obovata the variable ploidy is confirmed for the RFE (Primorskii Krai), the same situation is in China $(2 \mathrm{n}=2 \mathrm{x}, 4 \mathrm{x})$. Poa sajanensis is reported firstly from Europe (Komi Republic); besides, here it has new (aneuploid) cytotype $2 \mathrm{n}=$ c. 64 .

\section{ACKNOWLEDGEMENTS}

The authors are grateful to E.G. Rudyka for participation in chromosome numbers determinations and to A.P. Lactionov - for verification of Glycyrrbiza species.

\section{LITERATURE CITED}

Agapova, N.D., K.B. Arkharova, L.I. Vakhtina, E.A. Zemskova \& L.V. Tarvis 1993. Chromosome numbers in flowering plants of the flora of the USSR: Moraceae-Zygophyllaceae. Nauka, St.-Petersburg, 430 pp. (in Russian). [Агапова H.A., Архарова К.Б., Вахтина А.И., Земскова Е.А., Тарвис А.В. 1993. Числа хромосом цветковых растений флоры CССР: семейства Moraceae-Zygophyllaceae. СПб: Наука. 430 с.].

Antonova, N.N. \& V.V. Petrovsky. 1986. Stellaria longipes (Caryophyllaceae) and its relatives in the North-East Asia. Botanicheskii Zhurnal 71(1):57-66 (in Russian). [Антонова Н.Н., Петровский В.В. 1986. Stellaria longipes (Caryophyllaceae) и ее сородичи на Северо-Востоке Азии // Ботанический журнац. 1986. Т. 71, № 1. С. 57-66].

Chepinoga V.V. 2014. Chromosome numbers of plant species from Baikal Siberia. Nauka, Novossibirsk, 419 pp. (in Russian). [Чeпинога В.В. 2014. Хромосомные числа растений фморы Байкальской Сибири. Новосибирск: Наука. 419 с.].

Fedorov, A.A. (ed.) 1969. Chromosome numbers of flowering plants. Leningrad, 926 pp. (in Russian). [Хромосомные числа цветковых растений / под реА. А.А. ФёАорова.

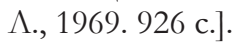

Guzik, M.B. 1984. Chromosome numbers of some grasses from natural flora of Predural'e. In: Ekologija opyleniya Rastenii. Mezhvuzovskij Sbornik. Nauchnykh Trudov, pp. 8286. Perm (in Russian). [Гузик М.Б. Хромосомные числа 
некоторых дикорастущих злаков Предуралья // Экомогия опыления растений. 1984. Межвузовский сборник научных трудов. Пермь. С. 82-86].

Hong, D., K. Pan \& G. Rao 2001. Cytogeography and taxonomy of the Paeonia obovata polyploid complex (Paeoniaceae). Plant Systematics and Evolution 227 (3-4):123-136.

Hong, D., Z. Zhang \& X. Zhu. 1988. Studies on the genus Paeonia (1) - report of karyotypes of some wild species in China. Acta Phytotaxonomica Sinica 26:33-43.

Korobkov, A.A., V.V. Kotseruba, N.S. Probatova, E.G. Rudyka \& A.A. Gnutikov 2012. IAPT/IOPB chromosome data 14 (K. Marhold, ed.). Taxon 61(6):1339-1340, E13-15.

Krasnikov, A.A. 1991. Chromosome numbers of some species of vascular plants from Novossibirskaya Oblast'. Botanicheskii Zhurnal 76(3):476-479 (in Russian). [Kpacников А.А. 1991. Числа хромосом некоторых видов сосудистых растений из Новосибирской об̆л. // Ботанический журнал. Т. 76, № 3. С. 476-479].

Mesǐcek, J. \& J. Sojăk 1995. Chromosome numbers of Mongolian angiosperms. II. Folia Geobotanica et Phytotaxonomica 30:445-453.

Nishikawa, T. (ed.) 2008. Chromosome atlas of flowering plants in Japan. National Museum of Nature \& Science Monographs, 37. Tokyo. 706 pp.

Probatova, N.S. 2014. Chromosome numbers in vascular plants of the Primorskii Krai (Russian Far East). Dal'nauka, Vladivostok, 343 pp. (in Russian). [Пробатова H.C. 2014. Хромосомные числа сосудистых растений Приморского края (АаАьний Восток России). ВАаАивосток: Аальнаука. 343 с.].

Probatova, N.S., A. A. Gnutikov, E.G. Rudyka \& V.V. Chepinoga 2008. Chromosome numbers of plant species from the Baikal Siberia. Botanicheskii Zhurnal 93(1):162-181 (in Russian). [Пробатова Н.С., Гнутиков А.А., Рудыка Э.Г., Чепинога В.В. 2008. Числа хромосом видов растений из Байкацьской Сибири // Ботанический журнац. T. 93, № 1. С. 162-181].

Probatova, N.S., S.G. Kazanovsky, V.Yu. Barkalov, E.G. Rudyka \& V.P. Seledets 2013. Chromosome numbers in vascular plants from various regions of Russia. Botanicheskii Zhurnal 98(2):255-268 (in Russian). [Пробатова Н.С., Казановский С.Г., Баркалов В.Ю., Рудыка Э.Г., Селелец В.П. 2013. Числа хромосом сосудистых растений из разных регионов России // Ботанический журнал. Т. 98, № 2. С. 255-268].

Probatova, N.S., S.G. Kazanovsky, E.G. Rudyka, V.P. Seledets \& V.A. Nechaev 2012. IAPT/IOPB chromosome data 13. (K. Marhold, ed.). Taxon 61(4):899-902, E34-42.

Probatova, N.S., S.G. Kazanovsky, A.V. Shatokhina, E.G. Rudyka, A.V. Verkhozina \& D.A. Krivenko 2012. IAPT/ IOPB chromosome data 14 (K. Marhold, ed.). Taxon 61(6):1342-1344, E23-28.

Probatova, N.S., A.A. Korobkov, A.A. Gnutikov, E.G. Rudyka, V.V. Kotseruba \& V.P. Seledets 2010. IAPT/IOPB chromosome data 10 (K. Marhold, ed.). Taxon 59(6): 1934-1937, E6-10.

Probatova, N.S., E.G. Rudyka, V.P. Seledets \& V.A. Nechaev 2008. IAPT/IOPB chromosome data 6 (K. Marhold, ed.). Taxon 57(4):1268-1271, E4-12.

Probatova N.S. \& V.P. Seledets 2008. IAPT/IOPB chromosome data 5 (K. Marhold, ed.). Taxon 57(2):555-558, E7-16.

Probatova, N.S., V.P. Seledets \& E.G. Rudyka 2016. IAPT/ IOPB chromosome data 22 (K. Marhold, ed.). Taxon 65 (5):1205-1206, E17-19.
Probatova, N.S., V.P. Seledets, E.G. Rudyka, A.A. Gnutikov, Z.V. Kozhevnikova \& V.Yu. Barkalov 2009. IAPT/ IOPB chromosome data 8 (K. Marhold, ed.). Taxon 58(4): 1284-1288, E11-20.

Probatova, N.S., V.P. Seledets, E.G. Rudyka, S.G. Kazanovsky \& V.Yu. Barkalov 2012. Chromosome numbers in some vascular plant species of the flora of Russia. Botanicheskii Zhurnal 97(6):814-831 (in Russian). [Пробатова Н.С., Семедец В.П., Рудыка Э.Г., Казановский С.Г., Баркалов В.Ю. 2012. Числа хромосом некоторых видов сосудистых растений фморы России // Ботанический журнал. Т. 97, № 6. С. 814-831].

Probatova, N.S., A.V. Verkhozina, E.G. Rudyka \& D.A. Krivenko 2013. IAPT/IOPB chromosome data 16 (K. Marhold, ed.). Taxon 62(6):1359-1360, E13-14.

Rudyka, E.G. 1990. Chromosome numbers in vascular plants from different regions of the U.S.S.R. Botanicheskii Zhurnal 75(12):1783-1786 (in Russian). [Рудыка Э.Г. 1990. Числа хромосом сосудистых растений из различных регионов СССР // Ботанический журнал. Т. 75, № 12. C. 1783-1786].

Sang, T. 2004. Origins of polyploids: an example from peonies (Paeonia) and a model for angiosperms. Biological Journal of the Linnean Society 82:561-571.

Sokolovskaya, A.P. 1972. Karyological characteristics of the representatives of the flora of Leningradskaya Oblast'. Vestnik Leningradskogo Universiteta. Biologiya 4:56-63 (in Russian). [Соколовская А.П. 1972. Кариологическая характеристика представителей флоры АенинграАской области // Вестник Аенингр. ун-та. Биол. Вып. 4. С. 56-63].

Sokolovskaya, A.P. \& N.S. Probatova 1968. Karyotaxonomic study on the Far Eastern species of Poa L. Botanicheskii Zhurnal 53(12):1737-1743 (in Russian). [Соколовская А.П., Пробатова Н.С. 1968. Кариосистематическое исслеАование дальневосточных видов Poa L. / / Ботанический журнал. Т. 53, № 12. С. 1737-1743].

Sokolovskaya, A.P. \& N.S. Probatova 1978. Chromosome numbers of some grasses (Poaceae) of the flora of U.S.S.R. II. Botanicheskii Zhurnal 63(9):1247-1257 (in Russian). [Coколовская А.П., Пробатова Н.С. 1978. Хромосомные числа некоторых злаков (Роасеае) флоры СССР. II // Ботанический журнал. Т. 63, № 9. С. 1247-1257].

Tzvelev, N.N. 2010. On the species of Poa L. (Poaceae) sect. Stenopoa Dumort. in the East Europe. Novitates systematicae plantarum vascularium 41:18-67 (in Russian). Цвелёв Н.Н. 2010. О вилах секции Stenopoa Dumort. рода мятлик (Poa L., Роасеае) в Восточной Европе // Новости систематики высших растений. Т. 41. С. 18-67].

Zhukova, P.G. 1967. Chromosome numbers in some plant species from Extreme North-East of the U.S.S.R. Botanicheskii Zhurnal 52(7):983-987 (in Russian). [Жукова П.Г. 1967. Хромосомные числа у некоторых вилов растений Крайнего Северо-Востока СССР // Ботанический журнац. Т. 52, № 7. С. 983-987].

Zhukova, P.G. 1982. Chromosome numbers of some plant species from Northeast Asia. Botanicheskii Zhurnal 65(1): 51-59 (in Russian). [Жукова П.Г. 1982. Хромосомные числа некоторых вилов растений Северо-Востока Азии // Ботанический журнал. Т. 65, № 1. С. 51-59].

Zhukova, P.G. \& V.V. Petrovsky 1980. Chromosome numbers and taxonomy of some plant species from An'ujskoe upland. Botanicheskii Zhurnal 65(5):651-659 (in Russian). [Жукова П.Г., Петровский В.В. 1980. Хромосомные числа и таксономия некоторых виАов растений Анюйского нагорья // Ботанический журнал. Т. 65, № 5. C. 651-659]. 